\title{
Universiteit
}

Leiden

The Netherlands

\section{Structure and DNA cleavage properties of two copper(II) complexes of the pyridine-pyrazole-containing ligands mbpzbpy and Hmpzbpya}

Maheswari, P.U.; Lappalainen, K.; Sfregola, M.; Barends, S.; Gamez, P.; Turpeinen, U.; ... ; Reedijk, J.

\section{Citation}

Maheswari, P. U., Lappalainen, K., Sfregola, M., Barends, S., Gamez, P., Turpeinen, U., ... Reedijk, J. (2007). Structure and DNA cleavage properties of two copper(II) complexes of the pyridine-pyrazole-containing ligands mbpzbpy and Hmpzbpya. Dalton Transactions, 2007(33), 3676-3683. doi:10.1039/b704390b

Version: $\quad$ Publisher's Version

License: $\quad$ Licensed under Article 25fa Copyright Act/Law (Amendment Taverne)

Downloaded from: https://hdl.handle.net/1887/3210246

Note: To cite this publication please use the final published version (if applicable). 


\title{
Structure and DNA cleavage properties of two copper(II) complexes of the pyridine-pyrazole-containing ligands mbpzbpy and Hmpzbpya $\uparrow+$
}

\author{
Palanisamy Uma Maheswari, ${ }^{a}$ Kristian Lappalainen, ${ }^{a}$ Michael Sfregola, ${ }^{a}$ Sharief Barends, ${ }^{a}$ Patrick Gamez, ${ }^{a}$ \\ Urho Turpeinen, ${ }^{b}$ Ilpo Mutikainen, ${ }^{b}$ Gilles P. van Wezel $^{a}$ and Jan Reedijk ${ }^{* a}$
}

\author{
Received 22nd March 2007, Accepted 21st May 2007 \\ First published as an Advance Article on the web 5th July 2007 \\ DOI: 10.1039/b704390b
}

The DNA-cleavage properties of the two copper(II) complexes, $\left[\mathrm{Cu}\left(\mathrm{mbpzbpy} \mathrm{Br}_{2}\right]\left(\mathrm{H}_{2} \mathrm{O}\right)_{2.5}(\mathbf{1})\right.$ and $\left[\mathrm{Cu}\right.$ (mpzbpya)Cl] $\left(\mathrm{CH}_{3} \mathrm{OH}\right)(2)$, obtained from the ligands 6,6'-bis(3,5-dimethyl- $N$-pyrazolmethyl)2,2'-bipyridine) (mbpzbpy) and 6'-(3,5-dimethyl- $N$-pyrazolmethyl)-2,2'-bipyridine-6-carboxylic acid) (Hmpzbpya), respectively, are reported. Upon coordination to $\mathrm{Cu}^{\mathrm{II}}$ chloride in methanol, one arm of the ligand mbpzbpy is hydrolyzed to form mpzbpya. Under the same experimental conditions, the reaction of mbpzbpy with $\mathrm{CuBr}_{2}$ does not lead to ligand hydrolysis. The ligand mpzbpya is coordinated to a copper(II) ion generating a $\mathrm{CuN}_{3} \mathrm{OCl}$ chromophore, resulting in a distorted square-pyramidal environment, whereas with the $\mathrm{N}_{4}$ mbpzbpy ligand, the $\mathrm{Cu}^{\mathrm{II}}$ ion is four-coordinated in a distorted square planar geometry. Both complexes promote the oxidative DNA cleavage of $\phi$ X174 phage DNA in the absence of reductant. The oxidative nature of the DNA cleavage reaction has been confirmed by religation and cell-transformation experiments. Studies using standard radical scavengers suggest the involvement of hydroxyl radicals in the oxidative cleavage of DNA. Although both compounds do convert form I (supercoiled) DNA to form II (nicked, relaxed form), only complex $\mathbf{1}$ is able to produce small amounts of form III (linearized DNA). This observation may be explained either by the attack of the copper(II) complexes to only one single strand of DNA, or by a single cleavage event. Statistical analysis of relative DNA quantities present after the treatment with both copper(II) complexes supports a random mode of DNA cleavage.

\section{Introduction}

The development of artificial chemical nucleases is essential in the field of biotechnology and drug design. ${ }^{1-3}$ The ability to accomplish site-specific DNA cleavage will undoubtedly allow the development of new chemotherapeutic agents and antimicrobial drugs. ${ }^{4-6}$ In addition, artificial nucleases will provide important new tools for DNA manipulation to molecular biologists. ${ }^{7,8}$ For example, a copper complex of 1,10-phenanthroline is used in DNA-footprinting experiments, which are important for the detailed study of DNA-protein interactions. ${ }^{9}$ Transition-metal complexes are well suited for application as artificial nucleases, because of their diverse structural features, and the possibility to tune their redox potential through the choice of proper ligands. ${ }^{10-17}$ Also, ligands can be designed to incorporate biological functional groups with a suitable metal ion to mimic the active sites found in metalloproteins. ${ }^{18}$

The efficiency of the DNA cleavage can be enhanced through the increase of the affinity of the metal complex for DNA. Successful,

${ }^{a}$ Leiden Institute of Chemistry, Leiden University, P.O. Box, 9502, 2300, RA Leiden, The Netherlands. E-mail: reedijk@chem.leidenuniv.nl; Fax: +31 715274671

${ }^{b}$ University of Helsinki, Department of Chemistry, Laboratory of Inorganic Chemistry, Helsinki, 00014, Finland

$\uparrow$ CCDC reference numbers 637327 \& 637328. For crystallographic data in CIF or other electronic format see DOI: $10.1039 / \mathrm{b} 704390 \mathrm{~b}$

\$ Electronic supplementary information (ESI) available: Fig. S1-S4 showing the hydrogen bonding and packing style for the complexes $\mathbf{1}$ and $\mathbf{2}$. See DOI: $10.1039 / \mathrm{b} 704390 \mathrm{~b}$ promising coordination compounds typically contain a DNAbinding moiety that targets either the major groove or the minor groove, and may additionally act as intercalator, thereby increasing the DNA-targeting ability of the metal complex. ${ }^{19,20}$ However, this procedure does not accurately characterize the in vivo activity of a chemical nuclease. The induced site-specificity is a difficult task in the design of DNA-cleaving agents. Most strategies used are based on the linkage of a DNA-recognition element to the chemical nuclease. Such DNA targeting can be achieved with either an antisense RNA, or with a highly specific DNA-binding protein, such as a zinc-finger motif.

The interaction of transition metals, like $\mathrm{Mn}, \mathrm{Fe}, \mathrm{Cu}$, with dioxygen (in the presence of a reductant) often generates reactive oxygen species that ultimately may cleave DNA. ${ }^{21}$ The cleavage mechanism can be either oxidative at the sugar or at the nucleobase, or hydrolytic at the phosphodiester backbone of DNA. The single- or double-strand oxidative DNA cleavage by redox-active metal complexes like $[\mathrm{Fe}(\text { edta })]^{2-}$ or $\mathrm{Cu}(1,10 \text {-phenanthroline })_{2} \mathrm{Cl}_{2}$, is initiated by the production of reactive oxygen species, like the hydroxyl radical or singlet oxygen through a Fenton-type mechanism. ${ }^{22-25}$ These free radicals abstract the most accessible and exposed sugar hydrogens and initiate the oxidative cleavage, leading to DNA-cleavage products. In fact the site of hydrogen atom abstraction from the DNA-sugar depends on the active metallonuclease used. This class of metallonucleases has potential applications in site-specific recognition of DNA and as DNA footprinting agents, however, their use in living cells (in-vivo) is limited as their activity towards DNA cleavage is only observed 
in the presence of excess of external reductants, such as sodium ascorbate or mercaptopropionic acid and dioxygen. The real challenge is the search for simple, synthetic metal complexes that bind and cleave DNA by a self-activating mechanism, also under in-vivo conditions.

Iron bleomycin was the first reported natural product to cleave DNA in an oxidative pathway, and its importance was soon recognized because of its novel and broad spectrum antitumor properties. ${ }^{26-28}$ The nuclease activity of this compound is self-activated through coordination to iron(II), in the presence of molecular dioxygen. ${ }^{29,30}$ The copper(II) adducts of 4methoxypyrrolic marine natural products were also reported to cleave DNA, in the absence of any reductant, suggesting the involvement of hydroxyl radicals. These $\mathrm{Cu}^{\mathrm{II}}$ compounds have also shown promising antitumor properties against breast-, colon- and liver-cancer cells by facilitating apoptosis. ${ }^{30-35}$ More recently, the complex $\left[\mathrm{Fe}\left(\mathrm{N}_{4} \mathrm{Py}\right)\left(\mathrm{CH}_{3} \mathrm{CN}\right)\right]\left(\mathrm{ClO}_{4}\right)_{2}$ was reported as a synthetic model of 'activated bleomycin', able to cleave DNA in the absence of reductant, owing to the formation of transient low-spin Fe(III)OOH species. ${ }^{14}$

We recently reported the discovery of a copper(II) complex, prepared from Hpyramol, that catalytically cleaves target DNA in the absence of reductant, by attacking multiple positions of the nucleotide. ${ }^{13}$ It was suggested that the DNA cleavage reaction is oxidative, through a non-diffusible radical mechanism, because radical scavengers do not significantly inhibit the DNA cleavage reaction. The above copper complex ${ }^{13}$ also shows interesting cytotoxic properties in selected cancer cell lines, comparable to the antitumor drug cisplatin. This copper complex is self-activated by the dehydrogenation of the precursor Hpyramol ligand upon coordination to the metal ion, i.e. the dehydrogenation of the ligand Hpyramol to Hpyrimol has now been observed with transition metals like $\mathrm{Cu}^{\mathrm{II}}, \mathrm{Fe}^{\mathrm{III}}, \mathrm{Mn}^{\mathrm{II}}$ and $\mathrm{Zn}^{\mathrm{II}}$. ${ }^{36,37}$ The oxidative DNA-cleavage mechanism appears to be purely ligand-based, as also the redox-inactive, zinc complex also shows DNA cleavage. ${ }^{38}$

In the present paper the synthesis and structures of two new, related copper(II) complexes, namely $\left[\mathrm{Cu}(\mathrm{mbpzbpy}) \mathrm{Br}_{2}\right]\left(\mathrm{H}_{2} \mathrm{O}\right)_{2.5}$ (complex 1) and $[\mathrm{Cu}(\mathrm{mpzbpya}) \mathrm{Cl}](\mathrm{MeOH})$ (complex 2), are described. Both complexes are soluble in water and cleave DNA without the presence of any added reductant. This is a valuable feature for an application as chemotherapeutic agents in anticancer treatments. DNA cleavage studies with various concentrations of the complexes have been performed on $\phi \mathrm{X} 174$ phage DNA. DNA cleavage investigations have also been carried out in the presence of different additives including selected radical scavengers, to clarify the mechanism of action of each complex. Religation and celltransformation experiments have been performed to determine the mode of DNA cleavage, i.e. hydrolytic, or oxidative. All studies suggest the involvement of hydroxyl radical species which generate DNA scissions via an oxidative mechanism.

\section{Results and discussion}

\section{Synthesis of the 'mbpzbpy' ligand}

The tetradentate ligand 'mbpzbpy' is synthesized from the commercially available compound 6,6'-dimethyl-2,2'-bipyridine (Scheme 1). 6,6'-Dimethyl-2,2'-bipyridine can also be prepared from 2-aminopicoline, which is first brominated by reaction

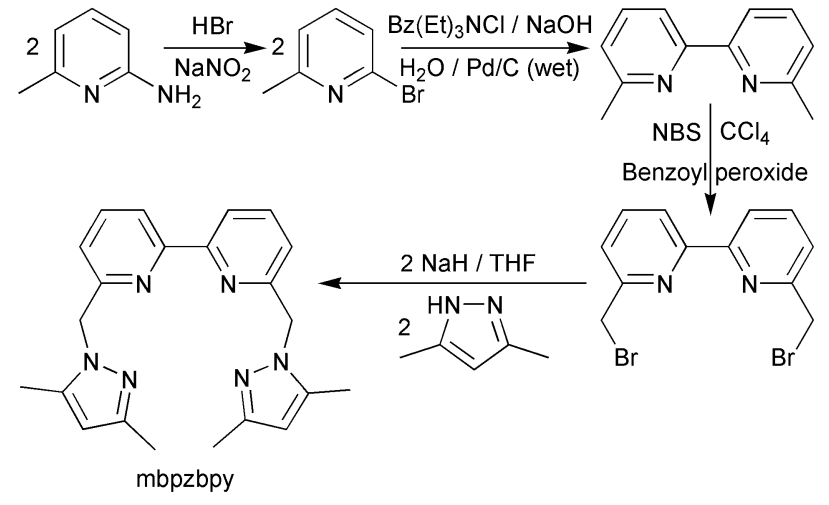

Scheme 1 Reaction pathway to synthesize the ligand mbpzbpy.

with $\mathrm{HBr}$ and $\mathrm{NaNO}_{2}$. The resulting 2-bromopicoline is purified by distillation (yield $=77 \%$ ). Next, the coupling reaction of 2-bromopicoline catalysed by wet $\mathrm{Pd} / \mathrm{C}$ produces, after nine days, 6,6'-dimethyl-2,2'-bipyridine with a yield of 50\%. 6,6'Dimethyl-2,2'-bipyridine is subsequently brominated with $\mathrm{N}$ bromosuccinimide (NBS) in refluxing $\mathrm{CCl}_{4}$ to yield the dibromide derivative 6,6'-bis(bromomethyl)-2,2'-bipyridine (yield $=21 \%$ ). The final step is the reaction between the dibromide derivative and the sodium salt of the 3,5-dimethylpyrazole, giving the ligand mbpzbpy (Fig. 1a) in good yields (77-94\%); details of the reaction conditions are given in the Experimental section.
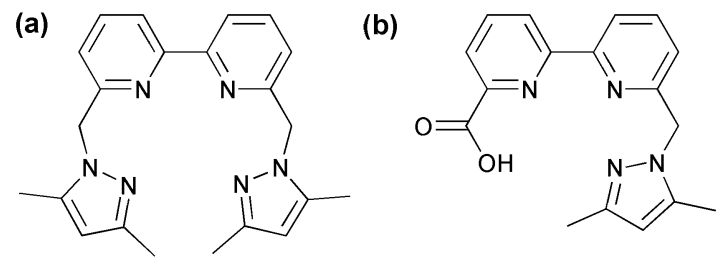

Fig. 1 Schematic representations of the ligands mbpzbpy (a) and Hmpzbpya (b).

\section{Preparation of the copper complexes}

The two complexes are prepared from $\mathrm{CuBr}_{2}$ and $\mathrm{CuCl}_{2} \cdot 6 \mathrm{H}_{2} \mathrm{O}$ and the ligand mbpzbpy [2-((3,5-dimethyl-1 $H$-pyrazol-1-yl)methyl)-6(6-((3,5-dimethyl-1 $H$-pyrazol-1-yl)methyl)pyridine-2-yl)pyridine] in absolute methanol. Starting from $\mathrm{CuCl}_{2} \cdot 6 \mathrm{H}_{2} \mathrm{O}$, the ligand mbpzbpy is modified to the partially hydrolysed ligand Hmpzbpya [6-(-((3,5-dimethyl-1 $H$-pyrazol-1-yl)methyl)pyridine-2-yl)pyridine-2-carboxylic acid] (Fig. 1b) yielding complex 2. Starting from $\mathrm{CuBr}_{2}$ the ligand has been found not to degrade under comparable conditions, yielding complex $\mathbf{1}$.

\section{Crystal structure descriptions}

$\left[\mathbf{C u}(\mathbf{m b p z b p y}) \mathrm{Br}_{2}\right]\left(\mathrm{H}_{2} \mathrm{O}\right)_{2.5}$ (1). The reaction of the ligand mbpzbpy with $\mathrm{CuBr}_{2}$ in absolute methanol yields dark blue crystals of 1 after one week. 1 crystallises in the $C 2 / c$ monoclinic space group. An ORTEP perspective view of complex $\mathbf{1}$ is depicted in Fig. 2. Selected bond lengths and angles are given in Tables 1 and 2, respectively. $\mathrm{The}^{\mathrm{Cu}}{ }^{\mathrm{II}}$ ion is in a distorted square-planar coordination environment formed by the $\mathrm{N}_{4}$ ligand. The distortion most likely arises from the small bite angle of the bipyridine moiety. 
Table 1 Selected bond lengths ( $\AA$ ) for complexes $\mathbf{1}$ and $\mathbf{2}$

\begin{tabular}{llll}
\hline Complex 1 & \multicolumn{3}{c}{ Complex 2 } \\
\hline Cu1-N21 & $1.992(2)$ & Cu1-N11 & $1.932(4)$ \\
Cu1-N21b & $1.992(2)$ & Cu1-N31 & $2.011(4)$ \\
Cu1-N11 & $2.010(2)$ & Cu1-O18 & $2.018(3)$ \\
Cu1-N11b & $2.010(2)$ & Cu1-N21 & $2.043(4)$ \\
Cu1-Br & $3.245(1)$ & Cu1-C11 & $2.4384(14)$ \\
\hline
\end{tabular}

Table 2 Selected bond angles $\left({ }^{\circ}\right.$ ) for complexes $\mathbf{1}$ and $\mathbf{2}$

\begin{tabular}{lllr}
\hline Complex 1 & \multicolumn{3}{l}{ Complex 2} \\
\hline N21-Cu1-N21b & $98.87(12)$ & N11-Cu1-N31 & $148.15(17)$ \\
N21b-Cu1-N11 & $93.06(8)$ & N11-Cu1-O18 & $80.98(15)$ \\
N21-Cu1-N11 & $93.06(8)$ & N31-Cu1-O18 & $102.51(15)$ \\
N11-Cu1-N11b & $80.95(11)$ & N11-Cu1-N21 & $78.97(16)$ \\
& & N31-Cu1-N21 & $91.43(16)$ \\
& & N11-Cu1-Cl1 & $111.50(12)$ \\
& & N31-Cu1-Cl1 & $99.42(12)$ \\
& & O18-Cu1-Cl1 & $98.34(11)$ \\
& & N21-Cu1-Cl1 & $94.66(12)$ \\
\hline
\end{tabular}

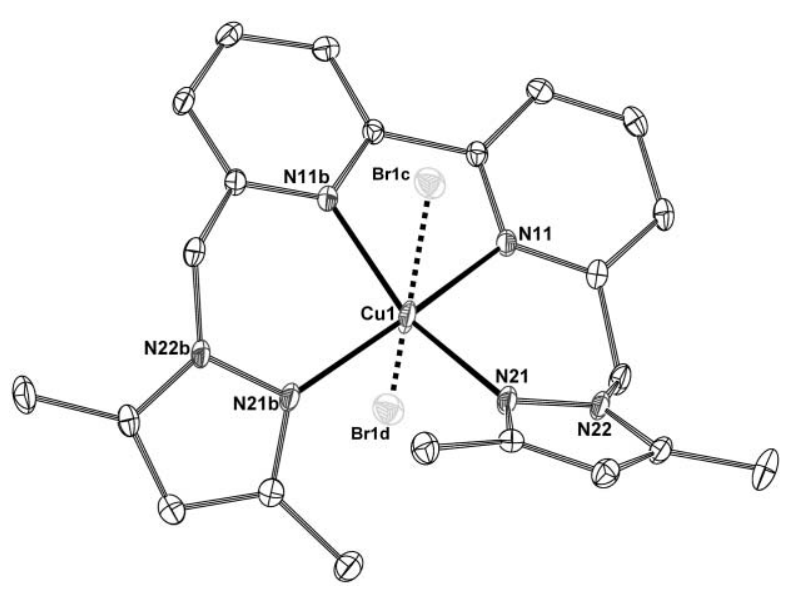

Fig. 2 ORTEP drawing (30\% probability level) of [Cu(mbpzbpy)$\left.\mathrm{Br}_{2}\right]\left(\mathrm{H}_{2} \mathrm{O}\right)_{2.5}$ (1). Hydrogen atoms and lattice water have been omitted for clarity. Symmetry operation codes: a: $-x, \mathrm{y}, 1 / 2-z ; \mathrm{b}: 1-x, y, 1 / 2-z$; c: $1 / 2-x, 1 / 2-y ; \mathrm{d}: 1 / 2+x, 1 / 2-y,-1 / 2+z$.

As a result, the two pyrazole rings deviate from the plane of the bipyridine unit to minimize the steric interactions between the methyl substituents. Thus, the $\mathrm{Cu}-\mathrm{N}$ distances involving the bipyridine unit are longer $(\mathrm{Cu} 1-\mathrm{N} 11=2.010(2) \AA, \mathrm{Cu} 1-\mathrm{N} 11 \mathrm{~b}=$ $2.010(2) \AA)$ than the pyrazole ones (Cu1-N21 = 1.992(2) $\mathrm{A}, \mathrm{Cu} 1-$ $\mathrm{N} 21 \mathrm{~b}=1.992(2) \AA)$. The equatorial $\mathrm{N}-\mathrm{Cu}-\mathrm{N}$ angles, varying from $80.95(11)$ to $98.87(12)^{\circ}$, reveal the strong geometric distortion induced by the bipyridine unit, and by the steric hindrance between two methyl groups of the pyrazole groups. The crystal packing of 1 shows that the bromide counter ions are interacting with the copper center, at semi-coordinating distances of the axial positions of the $\mathrm{N}_{4}$ plane $(\mathrm{Cu} \cdots$ Br separation of $3.245 \AA$, Fig. S1 $\ddagger)$. In fact, these bromide anions are also involved in a hydrogen bonding network with lattice water molecules (Fig. S2 $\ddagger$ ). Each bromide thus exhibits close contact with three water molecules (the $\mathrm{O}$ $\mathrm{H} \cdots \mathrm{Br}$ distances range from 3.369 to $3.453 \AA$ ).

$\left[\mathbf{C u}(\right.$ mpzbpya) $\mathrm{Cl}]\left(\mathrm{CH}_{3} \mathrm{OH}\right)$ (2). The room temperature reaction of the ligand mbpzbpy with $\mathrm{CuCl}_{2} \cdot 6 \mathrm{H}_{2} \mathrm{O}$ in absolute methanol yields light-green plate crystals of $\mathbf{2}$ after two weeks, the crystal structure reveals that the original mbpzbpy ligand had been converted to Hmpzbpya (Fig. 1). 2 crystallises in the $P-1$ triclinic space group. An ORTEP perspective view of $\mathbf{2}$ is shown in Fig. 3. Selected bond lengths and angles are given in Tables 1 and 2, respectively. The copper(II) ion is pentacoordinated in a highly distorted square-pyramidal environment (the $\tau$ factor amounts to $0.392)^{39}$ with a $\mathrm{N}_{3} \mathrm{OCl}$ donor set. The equatorial plane is defined by the two pyridine nitrogen atoms N11 and N21, the pyrazole nitrogen atom $\mathrm{N} 31$, and by the $\mathrm{O} 18$ atom from the carboxylate donor (Fig. 3). The apical position is occupied by the chloride anion $\mathrm{Cl1}$. The $\mathrm{Cu}-\mathrm{N}, \mathrm{Cu}-\mathrm{O}, \mathrm{Cu}-\mathrm{Cl}$ distances are in the expected ranges (Table 1). ${ }^{40}$ The basal angles varying from $78.97(16)$ to $102.51(15)^{\circ}($ Table 2$)$ reflect the significant distortion of the squarepyramid, stemming from the methylene group linking the pyrazole moiety to the bipyridine. Indeed, while N11, N21, and O18 are in the same plane, the pyrazole nitrogen N31 is out of this plane (Fig. S3 ). The crystal packing of $\mathbf{2}$ shows that the oxygen atom O19 from the carboxylate group is involved in a strong hydrogenbonding interaction with a lattice methanol molecule (the O1H1A ... O 19 distance is $2.715 \AA$, Fig. S4 ).

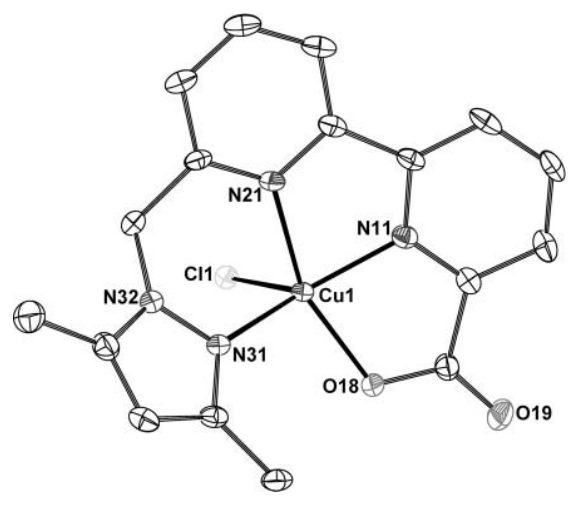

Fig. 3 ORTEP drawing (30\% probability level) of [Cu(mpzbpya)$\mathrm{Cl}](\mathrm{MeOH})$ (2). Hydrogen atoms and lattice $\mathrm{MeOH}$ has been left out for clarity.

Copper complexes from pyrazole ligands are known to mediate oxidation reactions; ${ }^{41}$ therefore, the $\left[\mathrm{Cu}(\mathrm{mbpzbpy}) \mathrm{Cl}_{2}\right]$ compound is believed to first oxidize one methylene group of the ligand in $\mathrm{MeOH}$, yielding ultimately the carboxylic acid product $(\mathrm{Hm}-$ pzbpya) after further oxidation (see Scheme 2).

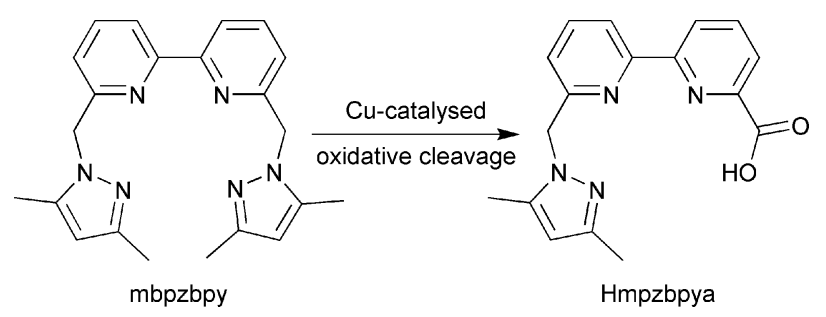

Scheme 2 Proposed pathway for the formation of Hmpzbpya.

\section{DNA cleavage properties}

Investigations of the DNA-cleaving abilities of both complexes $\mathbf{1}$ and $\mathbf{2}$ revealed cleavage activities in the absence of reductant, 


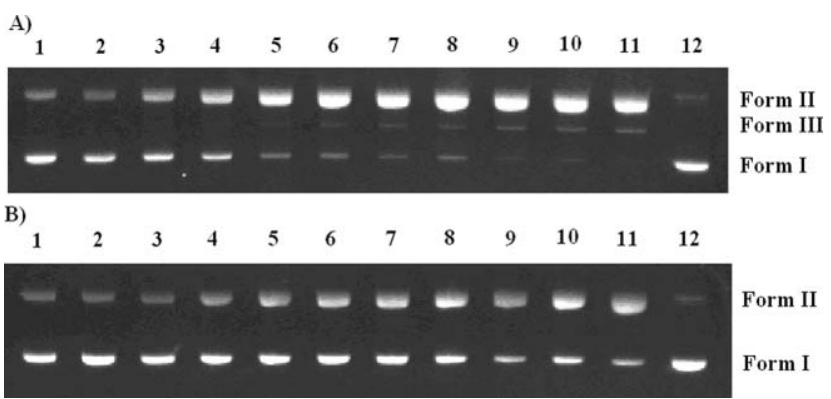

Fig. 4 Agarose gel electrophoresis of $\phi X 174$ DNA treated with increasing concentrations of complex 1 (A) or complex 2 (B). Lanes 1-11 represent the DNA cleavage using 20-220 $\mu \mathrm{M}$ of complex 1 or complex 2 (in $20 \mu \mathrm{M}$ increments) with $20 \mu \mathrm{M}$ (in base pairs) of $\phi$ X174 DNA. Incubation time was $2 \mathrm{~h}$ at $37^{\circ} \mathrm{C}$ for all reactions. Lane 12 is the DNA control without the copper complexes. Small amounts of form III are visible only for complex 1 .

after a reaction time of $2 \mathrm{~h}$ with $\phi \mathrm{X} 174 \mathrm{DNA}$ at $37^{\circ} \mathrm{C}$ (Fig. 4A, B). The reaction of complex 1 with $\phi \mathrm{X} 174 \mathrm{DNA}(20 \mu \mathrm{M}$, in base pairs) resulted in significant amounts of form II, and in more than stoichiometric amounts (around 1-10 fold). About $90 \%$ of the supercoiled DNA (form I) was nicked to produce relaxed or open circle DNA (form II), when incubated with $80 \mu \mathrm{M}$ complex 1 (Fig. 4A). Although this efficient DNA cleavage was promising, only a very small proportion of the DNA was linearized by complex 1 (Fig. 4A). Double-stranded DNA cleavage cannot be easily repaired by the host DNA repair system and is therefore much more desirable from the perspective of anti-cancer drug development for any DNA-cleaving transition metal complex.
Even though complex $\mathbf{1}$ did result in the formation of some linear DNA (Fig. 4A, form III), it cannot be assigned as direct double-strand cleavage as explained below. The ratio of doublestrand cuts to single-strand cuts was about $0.033: 1$ at a complex concentration of $220 \mu \mathrm{M}$. The number of double-strand breaks per molecule of DNA expected from completely random single-strand breaks is given by the Freifelder-Trumbo equation. ${ }^{42}$ The amount of double-strand breaks depends on the maximum separation in bases between cuts on complementary strands that can produce a linear molecule and the number of phosphodiester bonds in the plasmid. Using this statistical model, one would expect only one dsDNA break per about 100 ss DNA breaks. In the present study, the occurrence of approximately 0.033 double-strand breaks and 2.37 single-strand breaks per molecule is determined, and therefore the ratio is around 72 . The slightly lower value (72) compared to the expected one (100) indicates that a random cleavage path to the formation of linear DNA indeed is most likely taking place.

In contrast, complex 2, where the original ligand is partially hydrolysed, does not show any sign of linearized DNA (form III) at any stage, thus ruling out the possibility of direct doublestranded cleavage. Thus complex $\mathbf{2}$ accomplished the conversion of form I (supercoiled) to only form II DNA (nicked or singlestrand cut); even at a concentration as high as $220 \mu \mathrm{M}$, the highest concentration tested, still $23 \%$ of the initial form I of DNA remained intact in the reaction mixture (Table 4). The inability of complex 2 to produce linear DNA (form III) may be due to its reduced cleavage efficiency, as evidenced by the fact that in the presence of $220 \mu \mathrm{M}$ of complex 2 (Fig. 4B, lane 11) still less DNA is cleaved than in the case of complex 1 at $100 \mu \mathrm{M}$ (Fig. 4A, lane 5). Conversely, both the complexes 1 and $\mathbf{2}$ cleave supercoiled DNA

Table 3 Crystal data and structure refinement for $\left[\mathrm{Cu}(\mathrm{mbpzbpy}) \mathrm{Br}_{2}\right]\left(\mathrm{H}_{2} \mathrm{O}\right)_{2.5}(\mathbf{1})$ and $[\mathrm{Cu}(\mathrm{mpzbpya}) \mathrm{Cl}]\left(\mathrm{CH}_{3} \mathrm{OH}\right)(\mathbf{2})$

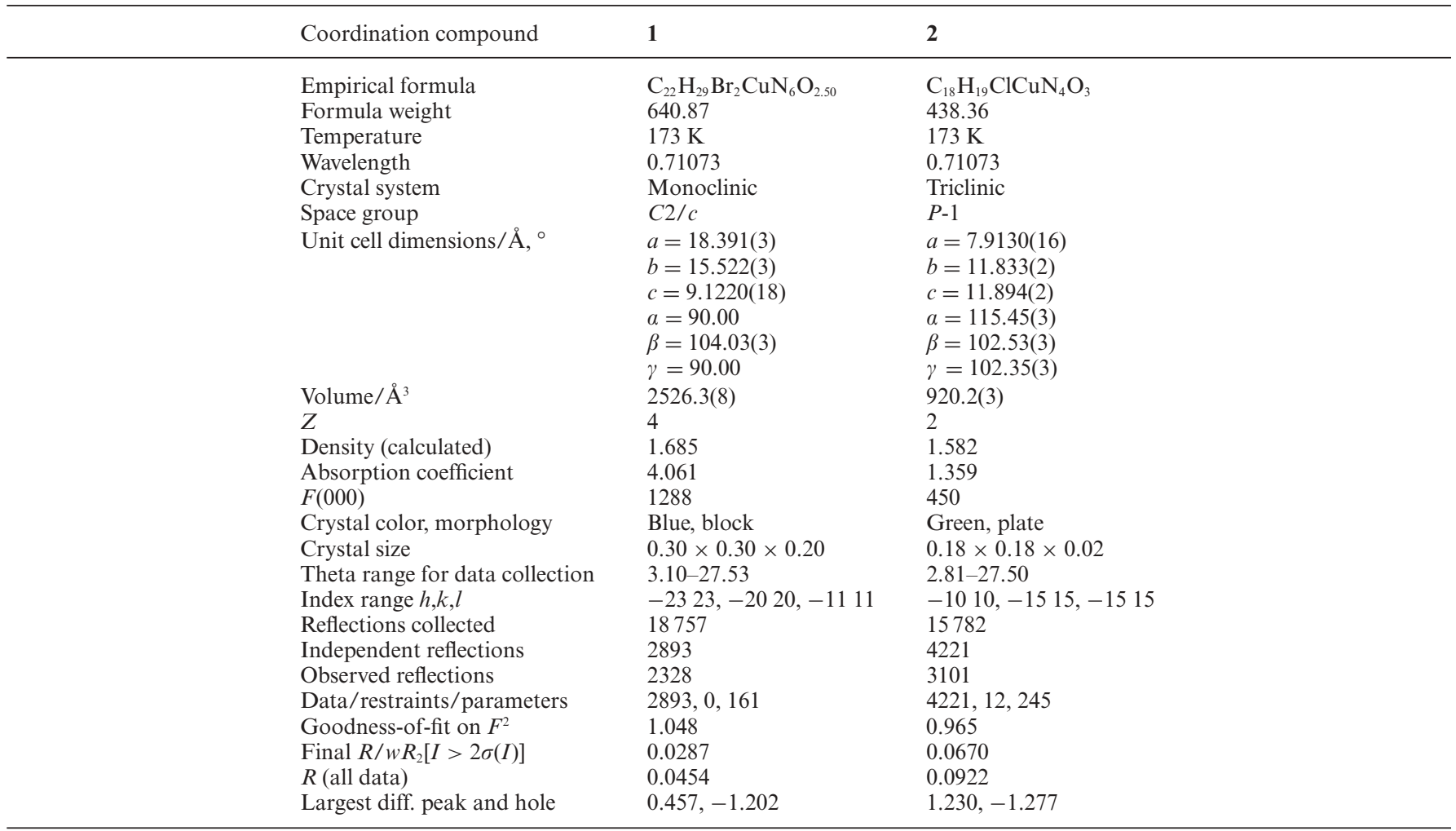


Table 4 Relative percentages of different forms of DNA after cleavage by the copper complexes $\mathbf{1}$ and $\mathbf{2}$

\begin{tabular}{llll}
\hline & Form I (\%) & Form II (\%) & Form III (\%) \\
\hline Complex 1 $100 \mu \mathrm{M}$ & 0.9 & 96 & 3.1 \\
Complex 2 $220 \mu \mathrm{M}$ & 23 & 77 & ${ }^{a}$
\end{tabular}

${ }^{a}$ Complex 2 shows no formation of form III, even at the highest concentration of $220 \mu \mathrm{M}$.

very efficiently to form III (linearized DNA) in the presence of the reducing agent ascorbic acid at a low concentration of $5 \mu \mathrm{M}$.

Evidence for an oxidative pathway for the cleavage of DNA has been obtained through religation and transformation of pUC19 plasmid cleavage products using complexes $\mathbf{1}$ and $\mathbf{2}$, containing form I and form II DNA. All ligation reactions contained the same total amount of DNA, but with different form I : form II ratios. Complex 2 at a concentration of $220 \mu \mathrm{M}$ converted about $75 \%$ of the DNA, while more than $90 \%$ of the initial DNA was converted by a $80 \mu \mathrm{M}$ solution of complex 1 (Fig. 5). As shown in Fig. 6, religation of the chemical cleavage experiments (obtained by the incubation of both complexes $\mathbf{1}$ and $\mathbf{2}$ with pUC19 plasmid) essentially gave lower transformation efficiencies as compared to control pUC19 plasmid (untreated with BamHI and T4 DNA ligase), and comparable to the digests not treated with T4 DNA ligase. Expectedly, in contrast to DNA cleaved chemically, we

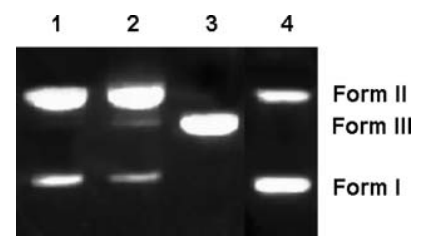

Fig. 5 Analysis of the cleavage reaction by determination of the religation efficiency. Lane 1, pUC19 DNA cleavage products treated with complex 1, $100 \mu \mathrm{M}$; Lane 2, $20 \mu \mathrm{M}$ DNA + complex 2, $220 \mu \mathrm{M}$; Lane 3, pUC19 DNA digested with BamHI (expectedly showing only linear DNA (form III)); Lane 4, untreated pUC19 DNA (20 $\mu \mathrm{M}$; control).

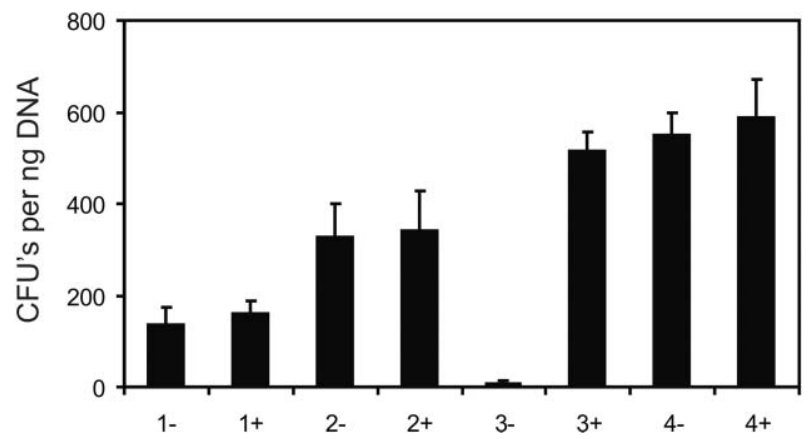

Fig. 6 Analysis of the cleavage reaction by determination of the religation efficiency. Samples refer to pUC19 plasmid DNA treated with: 1, Complex $1(100 \mu \mathrm{M})$; 2, Complex $2(220 \mu \mathrm{M})$; 3, Restriction enzyme BamHI, 4, untreated (transformation control). Samples were incubated with (+) or without (-) DNA ligase prior to transformation to E. coli JM109. CFU, colony forming units. BamHI-digested DNA was almost completely religated by the T4 DNA ligase, while very little religation was observed for DNA cleaved with either Complex $\mathbf{1}$ or Complex $\mathbf{2}$, suggesting the cleavage was oxidative. Error bars deduced from three independent experiments are shown. could efficiently religate the DNA that was linearized using the restriction enzyme Bam $\mathrm{HI}$, and subsequently religated using T4 DNA ligase as illustrated by the high transformation efficiency of $94 \%$, which is comparable to untreated control DNA $(100 \%$ by default). Fig. 6 indicates low transformation efficiency for the DNA cleaved by complex $\mathbf{1}$ in comparison to complex $\mathbf{2}$. As the undigested, initial form I of DNA is the only DNA giving rise to colonies in the cell-transformation experiments, the DNA cleavage is suggested to be oxidative, with probable alterations in the sugar and/or base units.

Further evidence for an oxidative mechanism of the DNA cleavage is achieved by additional DNA-cleavage reactions performed in the presence of standard radical scavengers, such as the enzyme superoxide dismutase (SOD), the minor groovespecific antibiotic distamycin, and by using the chemicals dimethyl sulfoxide (DMSO) and sodium azide $\left(\mathrm{NaN}_{3}\right)$ (Fig. 7 and 8$)$. The action of complex $\mathbf{2}$ is inhibited by DMSO, suggesting the potential involvement of hydroxyl radical intermediates in the oxidative DNA cleavage. The action of complex $\mathbf{1}$ is also inhibited in the presence of DMSO and, to a much lesser extent, by sodium azide. These results suggest the participation of hydroxyl radicals and singlet oxygen in the reaction. Interestingly, the DNA cleavage is seriously enhanced in the presence of SOD, sodium chloride, or in dark conditions (Fig. 8). Moreover, the DNA cleavage is also enhanced under anaerobic conditions, showing that cleavage may occur in an $\mathrm{O}_{2}$ independent manner, just as observed in prokaryotic systems. The enhanced oxidative DNA cleavage in the presence of SOD indicates that superoxide anions are not involved. However, the in situ production of $\mathrm{H}_{2} \mathrm{O}_{2}$ and its reaction with SOD ultimately may produce reactive oxygen species. The DNA cleavage is inhibited for both the complexes in the presence of distamycin, indicative of competitive binding interactions between the copper complexes and distamycin in the minor groove of DNA (Fig. 7, lane 5 for 1, and Fig. 8, lane 5 for 2). This observation

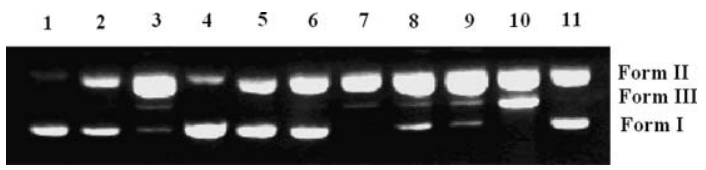

Fig. 7 Agarose gel electrophoresis of the oxidative cleavage reaction of $\phi$ X174 supercoiled phage DNA $(20 \mu \mathrm{M})$ with complex $\mathbf{1}(100 \mu \mathrm{M})$ after $2 \mathrm{~h}$ of incubation at $37^{\circ} \mathrm{C}$ in phosphate buffer (pH 7.2) (Lane 11). DNA was incubated with: Lane 1, no additives (control); Lane 2, $200 \mu \mathrm{M} \mathrm{NaN}_{3}$; Lane 3, $0.5 \mathrm{U}$ of superoxide dismutase, Lane 4, DMSO, Lane 5, $100 \mu \mathrm{M}$ distamycin, Lane 6, $\mathrm{D}_{2} \mathrm{O}$; Lane 7, under argon, Lane 8, in the dark, Lane 9, $350 \mu \mathrm{M} \mathrm{NaCl}$, Lane 10, $20 \mu \mathrm{M}$ ascorbic acid.

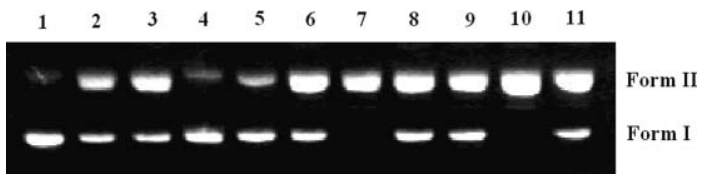

Fig. 8 Agarose gel electrophoresis of the oxidative cleavage reaction of $(20 \mu \mathrm{M}) \phi \mathrm{X} 174$ supercoiled phage DNA with complex $2(200 \mu \mathrm{M})$ after $2 \mathrm{~h}$ of incubation at $37^{\circ} \mathrm{C}$ in phosphate buffer (pH 7.2) (Lane 11). DNA was incubated with: Lane 1, no additives (control); Lane 2, $200 \mu \mathrm{M} \mathrm{NaN}_{3}$; Lane 3, $0.5 \mathrm{U}$ of superoxide dismutase, Lane 4, DMSO, Lane 5, $100 \mu \mathrm{M}$ distamycin, Lane 6, $\mathrm{D}_{2} \mathrm{O}$; Lane 7, under argon, Lane 8, under dark, Lane 9, $350 \mu \mathrm{M} \mathrm{NaCl}$, Lane 10, $20 \mu \mathrm{M}$ ascorbic acid. 
strongly indicates that the complexes $\mathbf{1}$ and $\mathbf{2}$ preferentially bind DNA in the minor groove, rather than in the major groove.

As stated above, the oxidative DNA cleavage properties of complexes $\mathbf{1}$ (form I to form II) and $\mathbf{2}$ are explicitly different. This difference can be explained (i) by a charge effect and/or (ii) a structural geometry effect. Complex 1 which has a $2+$ charge most likely experiences a better interaction with the negative DNA helix (as the two bromide anions are only at semi-coordinating positions in the crystal lattice) than the neutral complex $\mathbf{2}$ (as the chlorido and the carboxylato ligands are coordinated to the metal centre). The second aspect is the slightly distorted squareplanar environment of complex $\mathbf{1}$ with easily dissociated bromide anions. As a result, the cation part of $\mathbf{1}$ is expected to interact more efficiently with the DNA double helix, via static interactions (such as intercalation or electrostatic contacts) than the distorted square-pyramidal neutral complex 2.

It has been demonstrated that the oxidative cleavage of DNA in the absence of a reductant is possible with copper(II) complexes through an effective activation of molecular oxygen, generating reactive oxygen species. ${ }^{9}$ The favourable $\mathrm{Cu}(\mathrm{II})$ to $\mathrm{Cu}(\mathrm{I})$ redox potential is then coupled with a self-hydrogen abstraction from the DNA molecule (most probably from the sugar moieties). The occurrence of this process instigates a single DNA cleavage event, through a Fenton mechanism. This DNA cleavage may become catalytic if the ligands coordinated to the $\mathrm{Cu}$ ion facilitate the $\mathrm{Cu}(\mathrm{II}) / \mathrm{Cu}(\mathrm{I})$ cycle. ${ }^{38} \mathrm{In}$ the present case, complex $\mathbf{1}$ is more effective than complex 2 to undergo a single cleavage event, however, both compounds fail to cleave DNA in a catalytic manner. So the distinct cleavage efficiencies observed for the present complexes can be rationalized by their significantly different coordination geometries. Indeed, it has been shown that the coordination geometry plays an important role in $\mathrm{Cu}(\mathrm{II}) / \mathrm{Cu}(\mathrm{I})$ redox processes. ${ }^{43}$ Complex $\mathbf{1}$ which is square-planar, can more easily accommodate an electron in its co-planar $\mathrm{d}\left(\mathrm{x}^{2}-\mathrm{y}^{2}\right)$ orbital compared to complex $\mathbf{2 .}{ }^{44}$ Accordingly, $\mathbf{1}$ can easier proceed to $\mathrm{a} \mathrm{d}^{10}$ configuration and thus to a tetrahedral geometry, which is likely to occur with a Fenton-type mechanism. Complex 2 exhibits a distorted square-pyramidal geometry with a weak axial $\sigma$ bond (chlorido ligand) and a strong $\sigma$ bond in the basal plane (carboxylato moiety). ${ }^{45}$ As a result, the accommodation of an electron in the co-planar $\mathrm{dx}^{2}-\mathrm{y}^{2}$ orbital is unlikely to happen due to steric as well as electronic repulsive forces. ${ }^{45}$ Thus, complex 2 with a $\mathrm{CuN}_{3} \mathrm{O}$ chromophore and a distorted square pyramidal geometry is less efficient in DNA cleavage than complex 1, which exhibits a $\mathrm{CuN}_{4}$ core with a distorted square-planar geometry.

\section{Concluding remarks}

Even though both copper(II) complexes are soluble in water and cleave $\phi$ X174 DNA, under more than stoichiometric conditions without the presence of any reductant, both complexes fail to produce catalytic double-strand DNA cleavage. The DNA cleavage studies with various concentrations of the complexes performed on $\phi$ X174 phage DNA and in the presence of different additives including selected radical scavengers, indicate the mechanism of DNA cleavage to be oxidative with the involvement of reactive oxygen species, such as hydroxyl radicals. Religation and cell- transformation experiments have shown that the DNA cleavage reaction is oxidative rather than hydrolytic.

\section{Experimental}

\section{General}

All chemicals were used as obtained without further purification. Elemental analyses $(\mathrm{C}, \mathrm{H}, \mathrm{N})$ were carried out on a PerkinElmer 2400 series II analyzer. FTIR spectra were recorded with a Perkin-Elmer Paragon 1000 FTIR spectrophotometer, equipped with a Golden Gate ATR device, using the reflectance technique $\left(4000-300 \mathrm{~cm}^{-1}\right)$. The ligand field spectra of the compounds in solution were recorded in the $200-1100 \mathrm{~nm}$ range with a Cary 50 spectrophotometer. ${ }^{1} \mathrm{H}$ NMR spectra were recorded using a DPX 300 Bruker (300 MHz) instrument. Chemical shifts are reported in ppm (parts per million) relative to the solvent peak. Xband electron paramagnetic resonance (EPR) measurements were performed at $77 \mathrm{~K}$ in the solid state on a Jeol RE2x electron spin resonance spectrometer, using DPPH $(g=2.0036)$ as a standard.

\section{Syntheses}

\section{Synthesis of the ligand mbpzbpy and its precursors}

2-Bromopicoline. $10 \mathrm{~g}(92 \mathrm{mmol})$ of 2-aminopicoline were dissolved in $50 \mathrm{~mL}$ of $\mathrm{HBr}(47 \%)$ at RT. Then, the solution was cooled to $-20{ }^{\circ} \mathrm{C}$, and $13.3 \mathrm{~mL}(259 \mathrm{mmol})$ of cooled bromine were added dropwise over a period of $30 \mathrm{~min}$, maintaining the temperature at $-20{ }^{\circ} \mathrm{C}$. The resulting paste was stirred for $90 \mathrm{~min}$ at this temperature. Next, a solution of $17 \mathrm{~g}(246 \mathrm{mmol})$ of sodium nitrite in water $(25 \mathrm{~mL})$ was added dropwise. After that, the reaction mixture was allowed to warm to $15{ }^{\circ} \mathrm{C}$ for a period of $1 \mathrm{~h}$, and stirred for an additional $45 \mathrm{~min}$. The mixture was cooled to $-20{ }^{\circ} \mathrm{C}$, and treated with cooled aqueous $\mathrm{NaOH}$ $(67 \mathrm{~g}, 100 \mathrm{~mL})$. During the addition, the temperature was kept to $-10{ }^{\circ} \mathrm{C}$. Subsequently, the mixture was allowed to warm to room temperature, and stirred for $1 \mathrm{~h}$. The solution was extracted with ethyl acetate, dried over sodium sulfate, and filtered. The solvent was evaporated under reduced pressure to give a crude oil, which was distilled in vacuo, yielding a colourless liquid $\left(48-50^{\circ} \mathrm{C}\right.$, $1 \mathrm{mmHg}$ ), namely 2-bromopicoline. Yield: $12.3 \mathrm{~g}(77 \%) .{ }^{1} \mathrm{H}-\mathrm{NMR}$ $\left(\mathrm{CDCl}_{3}, 300 \mathrm{MHz}\right) \delta(\mathrm{ppm}) 2.54\left(\mathrm{~s}, 3 \mathrm{H}, \mathrm{CH}_{3}-\mathrm{C}(6)\right), 7.10(\mathrm{~d}, 1 \mathrm{H}$, $\mathrm{H}-\mathrm{C}(5)), 7.29$ (d, 1H, H-C(3)), 7.43 (t, 1H, H-C(4)).

6,6'-Dimethyl-2,2'-bipyridine. A mixture of 2-bromopicoline $(4.2 \mathrm{~g}, 24.4 \mathrm{mmol})$, sodium formate $(2.1 \mathrm{~g}, 30.8 \mathrm{mmol}), 10 \%$ wet $\mathrm{Pd} / \mathrm{C}(0.15 \mathrm{~g})$, benzyltriethylammonium chloride $(0.7 \mathrm{~g}$, $3.1 \mathrm{mmol}), \mathrm{NaOH}(84 \mathrm{mg}, 2.1 \mathrm{mmol})$ and $10 \mathrm{~mL}$ of water was refluxed for 9 days. Additional amounts of sodium formate $(0.1 \mathrm{~g})$ and $\mathrm{Pd} / \mathrm{C}$ catalyst $(0.01 \mathrm{~g})$ were added each day. After 9 days, the mixture was filtered. The water phase was extracted with dichloromethane, and the black solid material was washed with dichloromethane. The combined organic phase was dried over magnesium sulfate, filtered, and the solvent was evaporated under reduced pressure. The brown crude product was recrystallized twice from pentane and hexane. 6,6'-Dimethyl-2,2'-bipyridine was isolated as a slightly brown powder (yield $=1.1 \mathrm{~g}, 50 \%$ ). ${ }^{1} \mathrm{H}$-NMR $\left(\mathrm{CDCl}_{3}, 300 \mathrm{MHz}\right) \delta 2.63\left(\mathrm{~s}, 6 \mathrm{H}, \mathrm{CH}_{3}-\mathrm{C}\left(6,6^{\prime}\right)\right), 7.15(\mathrm{~d}, 2 \mathrm{H}, \mathrm{H}-$ $\left.\mathrm{C}\left(5,5^{\prime}\right)\right), 7.68\left(\mathrm{t}, 2 \mathrm{H}, \mathrm{H}-\mathrm{C}\left(3,3^{\prime}\right)\right), 8.18\left(\mathrm{~d}, 2 \mathrm{H}, \mathrm{H}-\mathrm{C}\left(4,4^{\prime}\right)\right) \mathrm{ppm}$. 
6,6'-Bis(bromomethyl)-2,2'-bipyridine. A mixture of 6,6'-dimethyl-2,2'-bipyridine $(2.76 \mathrm{~g}, 15.5 \mathrm{mmol})$ and $N$-bromosuccinimide $(5.10 \mathrm{~g}, 28.6 \mathrm{mmol})$ in $150 \mathrm{~mL}$ of $\mathrm{CCl}_{4}$ was refluxed for $30 \mathrm{~min}$, and $30 \mathrm{mg}$ of benzoyl peroxide were subsequently added. The resulting mixture was refluxed overnight, and the resulting succinimide by-product was filtered off. The solution was cooled to $0{ }^{\circ} \mathrm{C}$, and the ensuing precipitate was filtered and washed with $\mathrm{MeOH}$ to give $0.8 \mathrm{~g}$ of 6,6'-bis(bromomethyl)-2,2'-bipyridine. The $\mathrm{CCl}_{4}$ solution was evaporated under reduced pressure yielding a slightly yellow powder. This powder was washed with a solution of $\mathrm{MeOH}$ and $\mathrm{CH}_{2} \mathrm{Cl}_{2}(2: 98)$. The insoluble part gives another crop of product $0.3 \mathrm{~g}$ (total yield $=1.1 \mathrm{~g}, 21 \%) .{ }^{1} \mathrm{H}-\mathrm{NMR}\left(\mathrm{CDCl}_{3}\right.$, $300 \mathrm{MHz}) \delta 4.63\left(\mathrm{~s}, 4 \mathrm{H}, \mathrm{CH}_{2}-\mathrm{Br}\right), 7.47$ (dd, $J=7.7 ; 0.8 \mathrm{~Hz}$, $\left.2 \mathrm{H}, \mathrm{H}-\mathrm{C}\left(5,5^{\prime}\right)\right), 7.82\left(\mathrm{t}, J=7.8 \mathrm{~Hz}, 2 \mathrm{H}, \mathrm{H}-\mathrm{C}\left(4,4^{\prime}\right)\right), 8.39(\mathrm{dd}$, $\left.J=7.9 ; 0.7 \mathrm{~Hz}, 2 \mathrm{H}, \mathrm{H}-\mathrm{C}\left(3,3^{\prime}\right)\right) \mathrm{ppm}$. The reaction also gives other brominated side products which can be separated by column chromatography.

6,6'-Bis(3,5-dimethyl- $N$-pyrazolmethyl)-2,2'-bipyridine (mbpzbpy). The compound mbpzbpy was synthesized from 6,6'-bis(bromomethyl)-2,2'-bipyridine (1.0 g, $2.92 \mathrm{mmol}), 3,5$-dimethylpyrazole $(0.62 \mathrm{~g}, 6.5 \mathrm{mmol})$ and $\mathrm{NaH}(0.15 \mathrm{~g}, 6.5 \mathrm{mmol})$. The product was obtained as a white microcrystalline powder. (Yield = $0.66 \mathrm{~g}, 94 \%) .{ }^{1} \mathrm{H}-\mathrm{NMR}\left(\mathrm{CDCl}_{3}, 300 \mathrm{MHz}\right) \delta 2.24$ and $2.26(\mathrm{~s}, 6 \mathrm{H}$, $\mathrm{CH}_{3}$-pyrazol), 5.40 (s, $4 \mathrm{H}, \mathrm{CH}_{2}$-py), 5.89 (s, 2H, CH-pyrazol), $6.83\left(\mathrm{~d}, J=7.6 \mathrm{~Hz}, 2 \mathrm{H}, \mathrm{H}-\mathrm{C}\left(5,5^{\prime}\right)\right), 7.72(\mathrm{t}, J=7.8 \mathrm{~Hz}, 2 \mathrm{H}$, $\left.\mathrm{H}-\mathrm{C}\left(4,4^{\prime}\right)\right), 8.27\left(\mathrm{~d}, J=7.7 \mathrm{~Hz}, 2 \mathrm{H}, \mathrm{H}-\mathrm{C}\left(3,3^{\prime}\right)\right) \mathrm{ppm},{ }^{13} \mathrm{C}-\mathrm{NMR}$ $\left(\mathrm{CDCl}_{3}, 300 \mathrm{MHz}\right) \delta 11.2 ; 13.5 ; 54.5 ; 105.7 ; 119.7 ; 121.0 ; 137.9$; $139.8 ; 148.0 ; 155.4$ and $156.8 \mathrm{ppm}$, MS $(\mathrm{m} / \mathrm{z}) 372\left(\mathrm{M}^{+}, 100\right)$; IR $1572,1550,1425,785,780,602 \mathrm{~cm}^{-1}$.

\section{Synthesis of the copper complexes}

$\left[\mathbf{C u}(\mathbf{m b p z b p y}) \mathrm{Br}_{2}\right]\left(\mathbf{H}_{\mathbf{2}} \mathbf{O}\right)_{2.5} \mathbf{( 1 )} . \quad 0.268 \mathrm{mmol}$ of ligand $(0.1 \mathrm{~g})$ were dissolved in warm absolute methanol $(10 \mathrm{~mL})$. Then, a solution of $0.268 \mathrm{mmol}$ of $\mathrm{CuBr}_{2}(0.059 \mathrm{~g})$ in methanol was added dropwise to the ligand solution under stirring. The solution was stirred for $10 \mathrm{~min}$ and filtered. The filtrate was left in air for the slow evaporation of the solvent. Dark blue crystals of $\mathbf{1}$, suitable for X-ray diffraction, were obtained after one week (Yield $=18 \%$ ). IR (neat, $\mathrm{cm}^{-1}$ ): 2360, 1608, 1578, 1554, 1471, 1427, 1395, 1296, 1032, 861, 792, 691. UV-Vis (neat, nm): 472 (vide infra). Anal. calcd for $\mathrm{C}_{22} \mathrm{H}_{29} \mathrm{Br}_{2} \mathrm{CuN}_{6} \mathrm{O}_{2.50}$ : C, 41.23; $\mathrm{H}, 4.56 ; \mathrm{N}, 13.11 \%$. Found: $\mathrm{C}$, 41.20; H, 4.46; N, 13.11\%. The powder EPR spectrum exhibits a broad signal with a small anisotropy, centred around a $g$ value of 2.077. Frozen solution EPR in a MeOH glass, shows a nice axially resolved spectrum with $g \|=2.22$ and $A \|=178 \mathrm{G}$, with $g_{\perp}$ as 2.048 .

[Cu(mpzbpya) $\mathbf{C l}\left(\mathrm{CH}_{3} \mathrm{OH}\right)$ (2). $\quad 0.268 \mathrm{mmol}$ of ligand $(0.1 \mathrm{~g})$ were dissolved in warm absolute methanol $(10 \mathrm{~mL})$. Then, a solution of $0.268 \mathrm{mmol}$ of $\mathrm{CuCl}_{2} \cdot 6 \mathrm{H}_{2} \mathrm{O}(0.046 \mathrm{~g})$ in methanol was added dropwise to the ligand solution under stirring. The solution was stirred for $10 \mathrm{~min}$ and filtered. The filtrate was left in air for the slow evaporation of the solvent. Light green plates of $\mathbf{2}$, suitable for X-ray diffraction, were obtained after two weeks $($ Yield $=32 \%)$. IR (neat, $\left.\mathrm{cm}^{-1}\right): 3353,2360,1601,1575,1552,1432$, 1289, 1054, 792, 648. UV-Vis (neat, nm): 495 (vide infra). Anal. calcd for $\mathrm{C}_{18} \mathrm{H}_{19} \mathrm{ClCuN}_{4} \mathrm{O}_{3}$ : C, 49.34; $\mathrm{H}, 4.37 ; \mathrm{N}, 12.78 \%$. Found: C, 49.31; H, 4.36; N, 12.70\%. The powder EPR spectrum exhibits a broad signal without anisotropy centred around a $g$ value of 2.124. Frozen solution EPR in a MeOH glass, shows an axially resolved spectrum with $g \|=2.22$ and $A \|=175 \mathrm{G}$, with $g_{\perp}$ as 2.054 .

X-Ray crystal structure determinations. Crystallographic data and refinement details are given in Table 3. A crystal was selected for the X-ray measurements and mounted to the glass fiber using the oil drop method ${ }^{46}$ and data were collected at $173 \mathrm{~K}$ on a Nonius Kappa CCD diffractometer (Mo K $\alpha$ radiation, graphite monochromator, $\lambda=0.71073 \mathrm{~nm}$ ). The intensity data were corrected for Lorentz and polarization effects, and for absorption. The programs COLLECT ${ }^{47}$ SHELXS-97, ${ }^{48}$ SHELXL-9749 were used for data reduction, structure solution and structure refinement, respectively. The non-hydrogen atoms were refined anisotropically. The $\mathrm{H}$ atoms were introduced in calculated positions and refined with fixed geometry with respect to their carrier atoms. Rotation about the exocyclic $\mathrm{C}-\mathrm{C}$ bonds was allowed in the refinements of the riding methyl $\mathrm{H}$ atoms at $\mathrm{C} 26$ and $\mathrm{C} 27$ in compound 1. Rotation about the exocyclic $\mathrm{C}-\mathrm{C}$ bonds was allowed in the refinements of the riding methyl $\mathrm{H}$ atoms at $\mathrm{C} 36$ and $\mathrm{C} 37$ in compound 2.

DNA cleavage studies. Cleavage experiments were performed using $\phi$ X174 supercoiled DNA purchased from Invitrogen Life Technologies. Typical reactions were carried out using $20 \mu \mathrm{M}$ DNA (base pairs) in $10 \mathrm{mM}$ phosphate buffer, and incubated at $37^{\circ} \mathrm{C}$ for $2 \mathrm{~h}$. Reactions with various concentrations of copper complex, from $20 \mu \mathrm{M}$ to $220 \mu \mathrm{M}$, were performed. The reactions were stopped by the addition of loading buffer (bromophenol blue, xylene cyanol, and $25 \%$ ficoll). The cleavage reactions were analyzed by agarose gel electrophoresis. The reaction samples were loaded on $0.8 \%$ agarose gel containing ethidium bromide, and were run at $80 \mathrm{mV}$ for $60-90 \mathrm{~min}$ in a TBE buffer. After washing with de-ionized water, the gels were documented using a BioRad Gel Doc 1000 apparatus. Additional reactions were performed in the presence of several additives. Thus, standard radical scavengers such as $\mathrm{NaN}_{3}(100 \mu \mathrm{M})$, SOD (0.5 units), DMSO, distamycin $(100 \mu \mathrm{M})$, and $\mathrm{D}_{2} \mathrm{O}$ were used. The reactions were also carried out in the presence of ascorbic acid $(20 \mu \mathrm{M})$, excess sodium chloride $(350 \mu \mathrm{M})$, and under anaerobic and dark conditions.

Religation studies. The cleavage of pUC19 plasmid DNA were carried out essentially as described above. The cleavage of DNA achieved by the copper complexes was further analysed by gel electrophoresis. Additionally, positive and negative controls were carried out using undigested pUC19 and pUC19 treated with the restriction enzyme BamHI. The reactions mixtures were purified using a QIAGEN PCR purification kit, and the accurate DNA concentrations were measured using a NanoDrop ND-1000 spectrophotometer. $50 \mathrm{ng}$ of sample DNA were religated in a solution of $2 \mu \mathrm{L}$ of 10X ligation buffer with 1 unit of T4 DNA ligase in a total volume of $20 \mu \mathrm{L}$. Negative controls without ligase were also included. The reactions were incubated overnight at $16{ }^{\circ} \mathrm{C}$. These reactions were then used to transform $200 \mu \mathrm{L}$ of competent DH5 $\alpha$ cells. The cells were heat-shocked for $2 \mathrm{~min}$ in a $42{ }^{\circ} \mathrm{C}$ water bath, and then incubated at $37^{\circ} \mathrm{C}$ for $20 \mathrm{~min}$, following the addition of $800 \mu \mathrm{L}$ of medium. These samples were then plated on LB-agar containing carbenicillin at three different concentrations, i.e. 10,100 , and $900 \mu \mathrm{L}$. The plates were incubated 
overnight at $37^{\circ} \mathrm{C}$. All ligation reactions performed were carried out in duplicate.

\section{References}

1 M. J. Fernandez, B. Wilson, M. Palacios, M. M. Rodrigo, K. B. Grant and A. Lorente, Bioconjugate Chem., 2007, 18, 121-129.

2 N. H. Gokhale and J. A. Cowan, Chem. Commun., 2005, 5916-5918.

3 Y. Jin and J. A. Cowan, J. Am. Chem. Soc., 2005, 127, 8408-8415.

4 C. B. Chen, R. Landgraf, A. D. Walts, L. S. Chan, P. M. Schlonk, T. C. Terwilliger and D. S. Sigman, Chem. Biol., 1998, 5, 283-292.

5 M. Pitié, C. Boldron and G. Pratviel, in Advances in Inorganic Chemistry including Bioinorganic Studies, 2006, vol. 58, pp. 77-130.

6 G. P. Xiao, D. L. Cole, R. P. Gunsalus, D. S. Sigman and C. H. B. Chen, Protein Sci., 2003, 12, 192-192.

7 M. Pitié, A. Croisy, D. Carrez, C. Boldron and B. Meunier, ChemBioChem, 2005, 6, 686-691.

8 M. Pitié, C. J. Burrows and B. Meunier, Nucleic Acids Res., 2000, 28 , 4856-4864.

9 W. K. Pogozelski and T. D. Tullius, Chem. Rev., 1998, 98, 1089-1107.

10 S. Borah, M. S. Melvin, N. Lindquist and R. A. Manderville, J. Am Chem. Soc., 1998, 120, 4557-4562.

11 P. U. Maheswari and M. Palaniandavar, Inorg. Chim. Acta, 2004, 357, 901-912.

12 P. U. Maheswari and M. Palaniandavar, J. Inorg. Biochem., 2004, 98, 219-230.

13 P. U. Maheswari, S. Roy, H. den Dulk, S. Barends, G. van Wezel, B. Kozlevcar, P. Gamez and J. Reedijk, J. Am. Chem. Soc., 2006, 128, $710-711$.

14 G. Roelfes, M. E. Branum, L. Wang, L. Que and B. L. Feringa, J. Am. Chem. Soc., 2000, 122, 11517-11518.

15 M. Sam, J. H. Hwang, G. Chanfreau and M. M. Abu-Omar, Inorg. Chem., 2004, 43, 8447-8455.

16 K. Selmeczi, M. Giorgi, G. Speier, E. Farkas and M. Reglier, Eur. J. Inorg. Chem., 2006, 1022-1031.

17 N. H. Williams, B. Takasaki, M. Wall and J. Chin, Acc. Chem. Res., 1999, 32, 485-493.

18 L. J. Childs, J. Malina, B. E. Rolfsnes, M. Pascu, M. L. Prieto, M. L. Broome, P. M. Rodger, E. Sletten, V. Moreno, A. Rodger and M. J. Hannon, Chem.-Eur. J., 2006, 12, 4919-4927.

19 S. Dhar, M. Nethaji and A. R. Chakravarty, Dalton Trans., 2005, 344 348.

20 S. Dhar, D. Senapati, P. K. Das, P. Chattopadhyay, M. Nethaji and A. R. Chakravarty, J. Am. Chem. Soc., 2003, 125, 12118-12124.

21 T. D. Tullius and J. A. Greenbaum, Curr. Opin. Chem. Biol., 2005, 9, 127-134.

22 W. S. Bowen, W. E. Hill and J. S. Lodmell, Methods Enzymol., 2001, 25, 344-350.

23 K. B. Hall and R. O. Fox, Methods Enzymol., 1999, 18, 78-84.

24 H. Kobayashi, S. Oikawa, K. Hirakawa and S. Kawanishi, mutat res genet toxicol environ mutagen, 2004, 558, 111-120.
25 M. X. Li and N. Q. Li, Chem. J. Chin. Univ., 2001, 22, 1230 1232.

26 A. Decker, M. S. Chow, J. N. Kemsley, N. Lehnert and E. I. Solomon, J. Am. Chem. Soc., 2006, 128, 4719-4733.

27 S. E. Hashimoto, B. X. Wang and S. M. Hecht, J. Am. Chem. Soc., 2001, 123, 7437-7438.

28 D. H. Petering, W. B. Li, C. W. Xia, C. Q. Zhao and W. E. Antholine, J. Inorg. Biochem., 2001, 86, 85-85.

29 H. Sugiyama, T. Sera, Y. Dannoue, R. Marumoto and I. Saito, J. Am. Chem. Soc., 1991, 113, 2290-2295.

30 D. Suh, Y. K. Oh, B. C. Ahn, M. W. Hur, H. J. Kim, M. H. Lee, H. S. Joo and C. K. Auh, Exp. Mol. Med., 2002, 34, 326-331.

31 R. A. Manderville, M. W. Calcutt, J. Dai, G. Park, I. G. Gillman, R. E. Noftle, A. K. Mohammed, M. Dizdaroglu, H. Rodriguez and S. A. Akman, J. Inorg. Biochem., 2003, 97, 249-249.

32 M. S. Melvin, M. W. Calcutt, R. E. Noftle and R. A. Manderville, Chem. Res. Toxicol., 2002, 15, 742-748.

33 M. S. Melvin, D. C. Ferguson, N. Lindquist and R. A. Manderville, J. Org. Chem., 1999, 64, 6861-6869.

34 M. S. Melvin, J. T. Tomlinson, G. R. Saluta, G. L. Kucera, N. Lindquist and R. A. Manderville, J. Am. Chem. Soc., 2000, 122, 63336334.

35 G. Park, J. T. Tomlinson, M. S. Melvin, M. W. Wright, C. S. Day and R. A. Manderville, Org. Lett., 2003, 5, 113-116.

36 P. de Hoog, L. D. Pachon, P. Gamez, M. Lutz, A. L. Spek and J. Reedijk, Dalton Trans., 2004, 2614-2615.

37 L. D. Pachon, A. Golobic, B. Kozlevcar, P. Gamez, H. Kooijman, A. L. Spek and J. Reedijk, Inorg. Chim. Acta, 2004, 357, 36973702.

38 P. U. Maheswari, S. Barends, Ş. Özalp-Yaman, P. de Hoog, H. Casellas, S. J. Teat, C. Massera, M. Lutz, A. L. Spek, G. P. van Wezel, P. Gamez and J. Reedijk, Chem.-Eur. J., 2007, 13, 5213-5222.

39 A. W. Addison, T. N. Rao, J. Reedijk, J. Van Rijn and G. C. Verschoor, J. Chem. Soc., Dalton Trans., 1984, 1349-1356.

40 U. Mukhopadhyay, D. Choquesillo-Lazarte, J. Niclos-Gutierrez and I. Bernal, CrystEngComm, 2004, 6, 627-632.

41 R. W. M. ten Hoedt, F. B. Hulsbergen, G. C. Verschoor and J. Reedijk, Inorg. Chem., 1982, 21, 2369-2373.

42 L. F. Povirk, W. Wubker, W. Kohnlein and F. Hutchinson, Nucleic Acids Res., 1977, 4, 3573-3580.

43 A. W. Addison, M. Palaniandavar, W. L. Driessen, F. Paap and J. Reedijk, Inorg. Chim. Acta, 1988, 142, 95-100.

44 T. Pandiyan, M. Palaniandavar, M. Lakshminarayanan and H. Manohar, J. Chem. Soc., Dalton Trans., 1992, 3377-3384.

45 M. Palaniandavar, T. Pandiyan, M. Lakshminarayanan and H. Manohar, J. Chem. Soc., Dalton Trans., 1995, 455-461.

46 T. Kottke and D. Stalke, J. Appl. Crystallogr., 1993, 26, 615-619.

47 Nonius, COLLECT, 2002, Nonius BV, Delft, The Netherlands.

48 G. M. Sheldrick, SHELXS-97 Program for Crystal Structure Determination, 1997, University of Göttingen, Germany.

49 G. M. Sheldrick, SHELXL-97-2 Program for Crystal Structure Refinement, 1997, University of Göttingen, Germany. 